Research Journal of Applied Sciences 13 (5): 306-312, 2018

ISSN: $1815-932 \mathrm{X}$

(C) Medwell Journals, 2018

\title{
Evaluation of Major and Trace Elements of Orin-Ekiti Bauxitic Clay
}

\author{
A.O. Talabi, R.O. Obasi, A.O. Oyinloye, O.L. Ademilua, O.F. Adebayo, \\ O.A. Olaolorun and A.B. Eluwole \\ Department of Geology, Ekiti State University, P.M.B. 5363, Ado-Ekiti, Nigeria
}

\begin{abstract}
Bauxite is the main ore from which aluminum can be extracted economically. The major and trace elements of Orin-Ekiti bauxitic clay were evaluated to ascertain its degree of lateralization, provenance and suitability for industrial application. Twelve samples were collected and subjected to analysis employing ICP-MS (Agilent 7700). Results of the analysis revealed that the bauxitic clay composed mainly of $\mathrm{Al}_{2} \mathrm{O}_{3}$ (25.57-34.19 wt.\%), $\mathrm{SiO} 2$ (31.19-47.71 wt.\%), $\mathrm{Fe}_{2} \mathrm{O}_{3}\left(1.26-23.23\right.$ wt.\%) and $\mathrm{TiO}_{2}(0.18-4.33$ wt.\%) with LOI between 13.61 and 24.71 wt.\%. Alkalis and alkali earth elements showed low values probably because they have been leached out during chemical weathering. The oxides concentrations revealed poor grade deposit when compared to the standard bauxite chemical composition $\left(\mathrm{Al}_{2} \mathrm{O}_{3}>45 \%, \mathrm{Fe}_{2} \mathrm{O}_{3}<20 \%\right.$ and $\left.\mathrm{SiO}_{2}<5 \%\right)$ which is economically mineable. Among the trace elements, Ba has the highest concentration (ppm) ranging from 559.77-3389.67 followed by $\mathrm{Sr} 169.63-1327.38$ and $\mathrm{Zr}$ between 49.32 and 1334.17. Vanadium and $\mathrm{Ce}$ concentrations (ppm) ranged from 9.19- 419.48 and 49.60-1334.17, respectively. All other trace elements have concentrations $<100 \mathrm{ppm}$. The ternary plot of $\mathrm{Al}_{2} \mathrm{O}_{3}-\mathrm{Fe}_{2} \mathrm{O}_{3}-\mathrm{SiO}_{2}$ revealed moderate lateralization with 75 and $25 \%$ of the samples representing bauxitic clay and silica, respectively. The binary $\mathrm{Cr} / \mathrm{Ni}$ plot indicated that the bauxitic clay was of heterogeneous sources most likely from basic igneous and sedimentary rock. Orin bauxitic clay is not suitable for Al-ore beneficiation but could found uses in the production of refractory works, alum and fertilizers production.
\end{abstract}

Key words: Bauxitic clay, mobile elements, trace elements, lateritization, ternary plot, Al-ore beneficiation

\section{INTRODUCTION}

Bauxite is a naturally occurring heterogeneous material formed from lateritic soil that has been severely leached of silica and other soluble materials in wet tropical or subtropical climate. Bauxite represents lithified and non-lithified residual weathering product which is rich in alumina and low in alkali metals, alkali earth metals (Ayorinde, 2011). It comprise mainly one or more of hydrated aluminum mineral, gibbsite, boehmite and diaspore with other impurities such as silica, iron oxides, titanium oxide and other elements in minor to trace amount. Bauxite is typically classified according to its intended commercial application such as abrasive, cement, chemical, metallurgical and refractory.

More than $90 \%$ of the world's bauxite is produced by six countries. The top five world producers of bauxite in 2010 were Australia, China, Brazil, India and Guinea. About 21 countries reported bauxite mine production in 2004 and total world production increased by about 3\% compared with that of 2003. Australia, Brazil, China and Guinea accounted for about two-thirds of the total bauxite mined in 2004. At the current rate of consumption, total reported world reserves of bauxite are sufficient to meet cumulative world primary aluminum metal demand well beyond the 21 st century. Although, bauxite reserves are unevenly distributed throughout the world with approximately $90 \%$ in about a dozen countries, the sheer magnitude of these reserves (23 billion metric tons) is sufficient to ensure a readily accessible supply for the future (Plunkert, 2006). Approximately, $85 \%$ of the bauxite mined is ultimately converted into aluminum metal (Kogel et al., 2006) an additional 10\% goes to non-metal uses such as various form of alumina (the oxide of aluminum) and the remaining $5 \%$ goes to non-metallic grade bauxite applications.

In Nigeria, record has it that bauxite is abundant in commercially exploitable reserves spread around the states of Delta, Benue and Ekiti. Prior to 1999 when the operations of Aluminium Smelter Company of Nigeria (ALSCON) was suspended, it used to mine bauxite and also had an alumina refinery producing over 4,000 metric tons of aluminium ingots per day. RUSAL took over the plant in 2007 and have been since, working on reviving its overall operations. The plant has been processing raw materials supplied by RUSAL's Friguia refinery (Guinea) with a present capacity of 120,000 tonnes of aluminium. However, recently, Nigeria's Supreme Court stripped RUSAL of its ownership of ALSCON claiming its 2007 bid as illegal (http://en.wikipedia.org/wiki/

Corresponding Author: A.O. Talabi, Department of Geology, Ekiti State University, P.M.B. 5363, Ado-Ekiti, Nigeria 
Minera-industry-of-Africa). In Ekiti State, few researchers (Talabi et al., 2013; Babatunde and Dayo-Olagbende, 2015) have worked on orin bauxite. Talabi et al. (2013), researched into the preliminary geophysical evaluation of Orin bauxite deposit and concluded that four to six layers subsurface lithological formations of nearly similar degree of saturation were delineated with layers 3 of the sounding curves constituting the bauxite deposit with variable thicknesses range of 7.1-14.2 m. However, Babatunde and Dayo-Olagbende (2015) observed that the bauxite samples obtained from Orin-Ekiti is not suitable as a raw material for the production of aluminum using the Bayer process but can however, be channeled into production of refractory materials as well as chemical production of alum. A bauxite body which is economically mineable at present or in the foreseeable future, currently should have chemical composition of $>45 \% \mathrm{Al}_{2} \mathrm{O}_{3},<20 \%$ $\mathrm{Fe}_{2} \mathrm{O}_{3}$ and $<5 \% \mathrm{SiO}_{2}$.
Rocks constitute the principal material in the formation of bauxite. There is no restriction to types of rocks that could weathered to produce bauxite. It is believed that some rocks are more favourably disposed to weathering as well as leaching and would weather to produce bauxite more than the others. The present research, therefore, examined the geochemistry of Orin bauxite that outcropped along a road cut as well as petrography and geochemistry of surrounding country rocks to establish economic viability of the bauxite and which of the basement rocks readily weathered to bauxite.

Location and geology: Orin-Ekiti lies on latitude $7^{\circ} 49^{\prime} 48.00^{\prime \prime} \mathrm{N}$ and longitude $5^{\circ} 14^{\prime} 24.00^{\prime \prime} \mathrm{E}$ with undulating terrain. Field observation revealed topographic elevation that ranged between 535 and $588 \mathrm{~m}$ above sea level (Fig. 1). It has two main climates characterized by dry and wet season in a year. The dry season occurs between

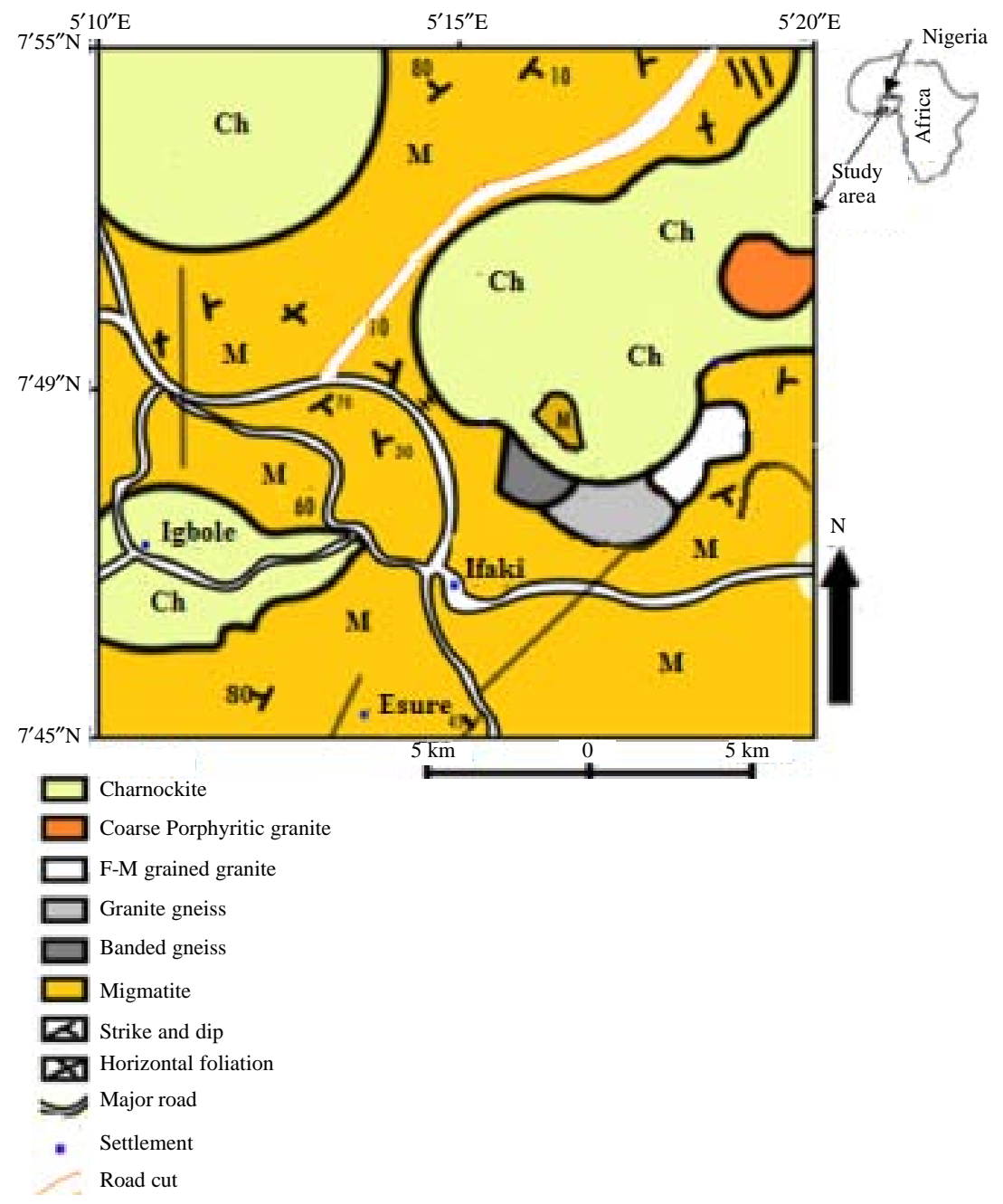

Fig. 1: Location and geologic map of the study area (Talabi et al., 2013) 
November and March while the wet season is between April and October. The average annual rainfall is $1333.2 \mathrm{~mm}$ with annual temperature ranging from $18-33^{\circ} \mathrm{C}$. The principal rock outcrops are granite gneiss, banded gneiss, granite and charnockite, especially, the coarse grained type (Fig. 1). Generally, the terrain is rugged with boulders of charnockite outcropping in few locations (Talabi et al., 2013). Most of the area is fairly accessible as it is connected with network of tarred and unpaved roads. Weathered rocks profiles developed along a road cut in the study area along which bauxite was formed.

\section{MATERIALS AND METHODS}

In this study, 12 samples from the lateritic bauxite Profiles (P1-P4) in the vicinity of charnockitic rocks were collected for geochemical analysis (Fig. 2). Samples P1S1-P1S3, P2S1-P2S3 and P3S1-P3S3 were collected along the exposed profile of lateritic bauxite in a road cut at Orin-Ekiti. For the whole-rock geochemical analysis, the samples were crushed to 200-mesh using electrical pulverizing machine. All analyses were carried out at the ICP-MSXRF Laboratory, Central Analytical Facility (CAF), Stellenbosch University, South Africa. Major elements were determined by a wet chemical method using the parallel samples and international standard samples for data quality control with precision better than $5 \%$. Trace elements were analyzed using a Perkin-Elmer ELAN-DRC-e ICP-MS. Results obtained from the analysis were subjected to data evaluation using Microsoft Excel, 2007.

\section{RESULTS AND DISCUSSION}

Physical characteristics of Orin bauxitic clay: Orin Bauxitic clay is unconsolidated with fine-coarse texture. It displays brownish grey, light grey or nearly white colour that indicates low iron content. The profiles, observed along the road cut comprises of top soil that supports plants grow (Fig. 2). The top layer is followed by hard indurated lateritic layer that grades into the bauxitic horizon. No other layer is observed after that of the Bauxitic as sampling terminated within the layer. However, the bauxitic layer is likely to grade into the saprolite that terminates in the basement rocks. The bauxitic clay in this profile falls into the category of lateritic bauxite deposit, produced by in situ tropical weathering and underlain by alumino-silicate or other rocks (Madourie, 2013).

The major, trace and rare earth element contents of the representative samples from four profiles of bauxitic deposits along a road cut in Orin-Ekiti are presented in Table 1 and 2 , respectively.

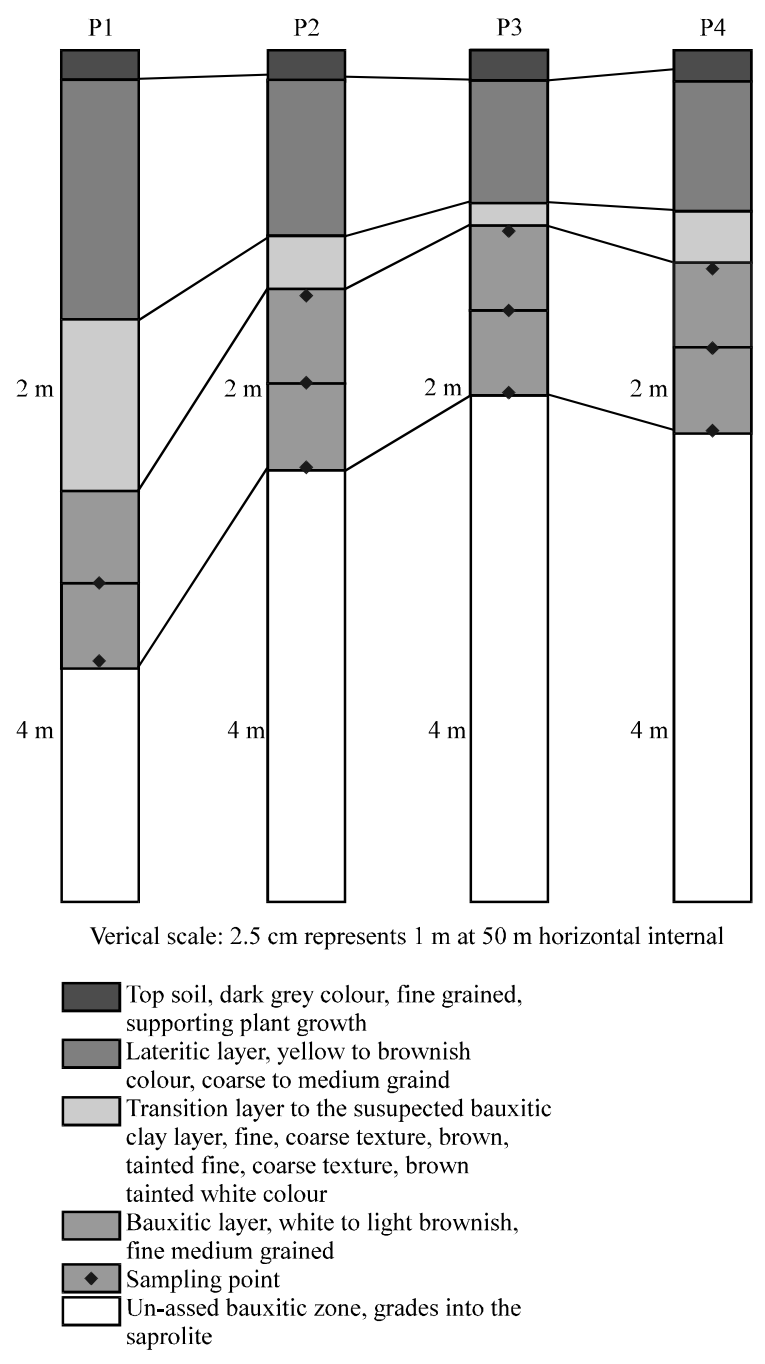

Fig. 2: Profiles indicating sampling points along road cut in the study area

Table 1: Summary ststistics of major elements in Orin-Ekiti bauxitic clay

\begin{tabular}{lrrrr}
\hline Oxide (wt.\%) & Min. & Max. & Mean & \multicolumn{1}{c}{ SD } \\
\hline $\mathrm{SiO}_{2}$ & 31.19 & 47.71 & 36.47 & 4.76 \\
$\mathrm{Al}_{2} \mathrm{O}_{3}$ & 25.57 & 34.19 & 29.30 & 3.22 \\
$\mathrm{SiO}_{2} / \mathrm{Al}_{2} \mathrm{O}_{3}$ & 1.02 & 1.40 & 1.24 & 1.48 \\
$\mathrm{Fe}_{2} \mathrm{O}_{3}$ & 1.26 & 23.23 & 12.55 & 8.06 \\
$\mathrm{CaO}$ & 0.02 & 0.29 & 0.08 & 0.08 \\
$\mathrm{MgO}$ & $<0.01$ & $<0.01$ & $<0.01$ & $<0.00$ \\
$\mathrm{Na}_{2} \mathrm{O}$ & $<0.01$ & 0.05 & 0.02 & 0.02 \\
$\mathrm{~K}_{2} \mathrm{O}$ & 0.01 & 0.17 & 0.06 & 0.06 \\
$\mathrm{MnO}_{\mathrm{TiO}}$ & 0.01 & 0.15 & 0.06 & 0.04 \\
$\mathrm{Cr}_{2} \mathrm{O}_{3}$ & 0.18 & 4.33 & 2.14 & 1.54 \\
$\mathrm{P}_{2} \mathrm{O}_{5}$ & $<0.01$ & $<0.01$ & $<0.01$ & $<0.01$ \\
$\mathrm{LOI}$ & 0.41 & 6.94 & 1.77 & 2.17 \\
$\mathrm{Total}$ & 13.61 & 24.71 & 16.46 & 2.96 \\
& 92.47 & 101.60 & 98.89 & 2.83 \\
\hline
\end{tabular}

Major elements: The ores are mainly composed of $\mathrm{Al}_{2} \mathrm{O}_{3}\left(25.57-34.19\right.$ wt.\%), $\mathrm{SiO}_{2}\left(31.19-47.71\right.$ wt.\%), $\mathrm{Fe}_{2} \mathrm{O}_{3}$ (1.26-23.23 wt.\%) and $\mathrm{TiO}_{2}(0.18-4.33$ wt.\%) with LOI ranging from 13.61-24.71 wt.\% (Table 1). 
Res. J. Applied Sci., 13 (5): 306-312, 2018

\begin{tabular}{|c|c|c|c|c|}
\hline Elements & Min. & Max. & Mean & SD \\
\hline $\mathrm{V}$ & 9.19 & 419.48 & 168.98 & 146.47 \\
\hline $\mathrm{Cr}$ & 17.49 & 440.20 & 78.98 & 116.36 \\
\hline $\mathrm{Ni}$ & 5.61 & 158.57 & 35.64 & 42.35 \\
\hline $\mathrm{Zn}$ & 50.01 & 159.87 & 97.50 & 36.57 \\
\hline $\mathrm{Rb}$ & 0.70 & 211.57 & 75.37 & 74.45 \\
\hline $\mathrm{Sr}$ & 169.63 & 1327.38 & 518.18 & 345.16 \\
\hline $\mathrm{Zr}$ & 49.32 & 1334.17 & 383.50 & 414.27 \\
\hline $\mathrm{Ba}$ & 559.77 & 3389.67 & 1388.75 & 789.04 \\
\hline $\mathrm{La}$ & 22.84 & 201.20 & 81.02 & 47.13 \\
\hline $\mathrm{Ce}$ & 49.60 & 400.47 & 170.13 & 96.41 \\
\hline$\underline{\mathrm{Nd}}$ & 22.13 & 176.05 & 85.54 & 45.56 \\
\hline
\end{tabular}

Alkalis and alkali earth elements show low values, probably because these elements being highly mobile have been leached out during chemical weathering. $\mathrm{MgO}$ and $\mathrm{Cr}_{2} \mathrm{O}_{3}$ essentially have concentrations less than the detection level of 0.01 . This trend also, occurred in $75 \%$ concentration values of $\mathrm{Na}_{2} \mathrm{O}$. Observing the oxides concentrations closely revealed non suitability of the chemical array for bauxitization. A bauxite body which is economically mineable at present or in the foreseeable future, currently should have chemical composition of $\mathrm{Al}_{2} \mathrm{O}_{3}<45 \%, \mathrm{Fe}_{2} \mathrm{O}_{3}<20 \%$ and $\mathrm{SiO}_{2}<5 \%$. The reflected oxides composition in this study clearly showed that the clay deposit has not been sufficiently lateritized/leached to form bauxite. $\mathrm{Al}_{2} \mathrm{O}_{3}$ and $\mathrm{TiO}_{2}$ that are common in Bauxite are immobile while $\mathrm{SiO}_{2}, \mathrm{Fe}_{2} \mathrm{O}_{3}$, the alkali and alkali earth are all readily mobile (Wilson, 2004).

Major and trace elements: Among the major elements, $\mathrm{Al}_{2} \mathrm{O}_{3}$ versus $\mathrm{TiO}_{2}$ as well as $\mathrm{Al}_{2} \mathrm{O}_{3}$ versus $\mathrm{Fe}_{2} \mathrm{O}_{3}$ showed the highest negative correlation $(\mathrm{r}=-0.9)$ while $\mathrm{Al}_{2} \mathrm{O}_{3}$ and $\mathrm{SiO}_{2}$ displayed a positive correlation $(\mathrm{r}=0.53)$ (Fig. 3). These patterns are not consistent with the fundamental requirements of leaching of silica and residual enrichment of aluminum and titanium during chemical weathering in the process of bauxitization though $\mathrm{MgO}, \mathrm{MnO}, \mathrm{Na}_{2} \mathrm{O}$, $\mathrm{K}_{2} \mathrm{O}$ and $\mathrm{CaO}$ nearly disappeared indicating that they were extremely mobile. The source rock probably has low alumina and high silica contents. The trace elements especially $\mathrm{Ba}, \mathrm{Sr}, \mathrm{Zr}, \mathrm{V}$ and $\mathrm{Ce}$ were enriched in the bauxitic-lateritic profiles.

Among the trace elements, $\mathrm{Ba}$ has the highest concentration ranging from 559.77-3389.67 (av. $1388.750 \mathrm{ppm}$ followed by $\mathrm{Sr}$ that ranged from 169.63-1327.38 (av. 518.18) ppm while $\mathrm{Zr}$ ranged from 49.32-1334.17 (av. 383.50) ppm. Vanadium and Ce ranged from 9.19-419.48 (av. 168.98) and 49.60-1334.17 (av. 383.50) $\mathrm{ppm}$, respectively (Table 2). All the remaining trace elements ( $\mathrm{Nb}, \mathrm{Ni}, \mathrm{Cu}, \mathrm{Zn}, \mathrm{Rb}, \mathrm{Y}, \mathrm{La}, \mathrm{Nd}, \mathrm{Sm}, \mathrm{Eu}, \mathrm{Gd}, \mathrm{Tb}$, $\mathrm{Dy}, \mathrm{Ho}, \mathrm{Er}, \mathrm{Tm}, \mathrm{Yb}, \mathrm{Lu}, \mathrm{Hf}, \mathrm{Ta}, \mathrm{Pb}$, Th and $\mathrm{U}$ ) have maximum concentration $(\mathrm{ppm})<100 \mathrm{ppm}$ and they are not reflected in Table 2.
Immobile elements geochemical approach is employed to trace the Orin bauxitic clay precursor. The mobility of the elements during bauxitization process is examined. Elements considered immobile will have their distribution producing a linear array that passes through the origin of their binary plot (MacLean et al., 1997). Plotting $\mathrm{Ba}, \mathrm{Sr}$ and $\mathrm{Zr}$ against $\mathrm{Al}_{2} \mathrm{O}_{3}$ (Fig. 3), the mobility of the trace elements is evaluated. $\mathrm{Ba}, \mathrm{Sc}$ and $\mathrm{Zr}$ produced linear relationship with very low correlation coefficient $(0.04 \leq \mathrm{r} \leq 0.36)$ revealing that conditions for baxitization was not favoured as $\mathrm{Al}_{2} \mathrm{O}_{3}$ is immobile and would have high positive correlation with the trace elements.

Bauxitic clay lithology: The triangular variation diagrams of $\mathrm{Al}_{2} \mathrm{O}_{3}+\mathrm{TiO}_{2}-\mathrm{SiO}_{2}-\mathrm{Fe}_{2} \mathrm{O}_{3}$ are commonly used to show the degree of lateralization, mineral control and bauxite classification (Balasubramaniam et al., 1987; Aleva and Creutzberg, 1994)

The trivariate plot for the bauxitic clay samples from the study area on the $\left(\mathrm{Al}_{2} \mathrm{O}_{3}+\mathrm{TiO}_{2}\right)-\mathrm{SiO}_{2}-\mathrm{Fe}_{2} \mathrm{O}_{3}$ diagram), indicated that most of the samples from the road cut profiles at Orin-Ekiti are bauxitic clay $(75 \%)$ while the remaining $25 \%$ samples are sandy clay (Fig. 4). According to the classification by Valeton (1972) using the molecular ratio of $\left(\mathrm{SiO}_{2} / \mathrm{Al}_{2} \mathrm{O}_{3}\right)$, the analyzed bauxitic clay samples are of low quality with the ratio ranging between 1.02 and 1.40 as $\mathrm{SiO}_{2}$ content is higher than $\mathrm{Al}_{2} \mathrm{O}_{3}$ contrary to the required chemistry of bauxite. Nevertheless, ternary plot of $\mathrm{Al}_{2} \mathrm{O}_{3}-\mathrm{Fe}_{2} \mathrm{O}_{3}-\mathrm{SiO}_{2}$ (Schellmann, 1982; Meyer et al., 2002) indicates that chemical variability is process-related and can be explained by different degrees of the lateritization, so that, $\mathrm{SiO}_{2}$-rich samples experienced weak lateritization while $\mathrm{Al}_{2} \mathrm{O}_{3}$-rich composition is indicative of a higher degree of lateralization. The samples in this study experienced moderate lateritization (Fig. 5) and as such might not form bauxite in which a higher degree of lateralization is required.

Source rock: Bauxitization is a process that does not discriminate against source rocks but rather depends heavily on surrounding geological conditions. Rocks that are generally or moderately high in alumina content and have a relatively large percentage of soluble constituents are predisposed to laterization and bauxitization (Patterson et al., 1986). In this study, the concentrations of certain trace elements of the analyzed bauxite were employed in an attempt to trace the nature of their likely precursor rocks. Plots of the Orin bauxitic clay data on the binary $\mathrm{Cr} / \mathrm{Ni}$ correlation (Fig. 6) proposed by Schroll (1968) revealed that the majority of the samples $(50 \%)$ fell into the high iron lateritic bauxite within the granite, sandstone source rocks, $42 \%$ of the samples were close to the shale-slate source while $8 \%$ was in the karst 
Res. J. Applied Sci., 13 (5): 306-312, 2018
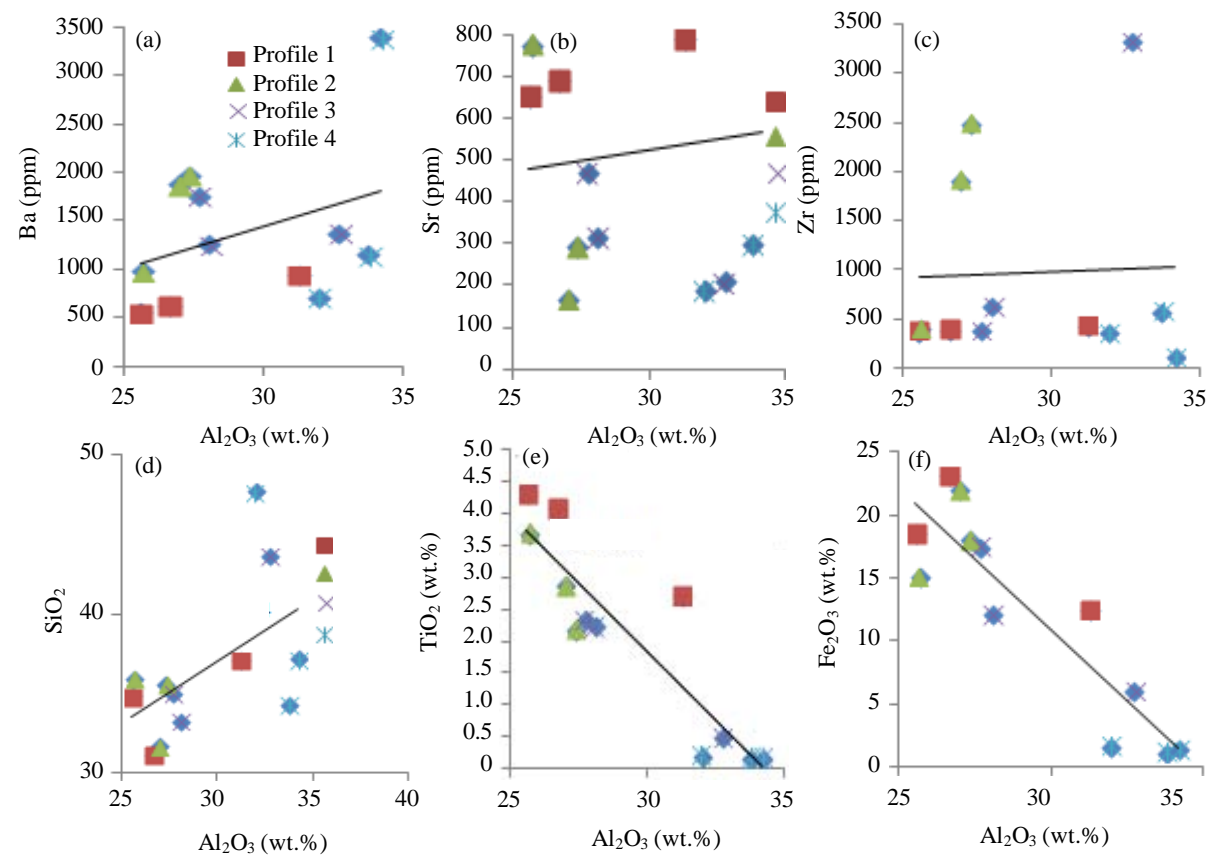

Fig. 3: Plots of few oxides and trace elements (ppm) versus $\left.\left.\left.\mathrm{Al}_{2} \mathrm{O}_{3} ; \mathrm{a}\right) \mathrm{R}=0.36 ; \mathrm{b}\right) \mathrm{R}=0.10 ; \mathrm{c}\right) \mathrm{R}=0.04 ; \mathrm{d}$ ) $\mathrm{R}=0.54$; ) $R=0.90$ and $f) R=-0.09$

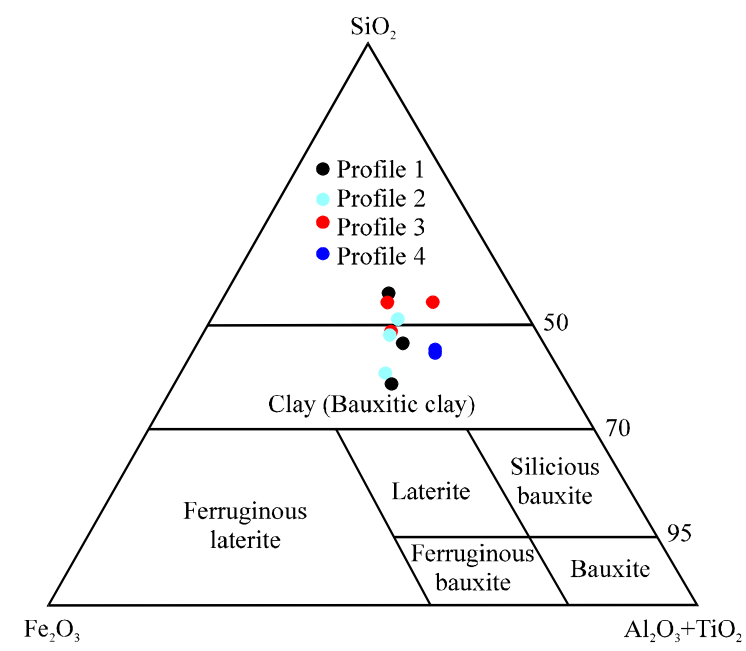

Fig. 4: Ternary plot for the system of $\mathrm{SiO} 2, \mathrm{Fe}_{2} \mathrm{O}_{3}$ and $\left(\mathrm{Al}_{2} \mathrm{O}_{3}+\mathrm{TiO}_{2}\right)($ Balasubramaniam et al., 1987)

bauxite zone with basaltic source rock. There is no doubt that, charnockites (a variety of granite containing minerals like orthopyroxene, quartz and feldspar) that are found as outcrops close to the bauxitic clay deposit contributed to bauxitization as source rock but there are other source rocks that contributed to the formation of the bauxitic clay in the area. The bauxitic clay was most likely to have originated from basic igneous and sedimentary rocks. Apart from the plot of $\mathrm{Cr}$ vs. $\mathrm{Ni}$ as discussed earlier,

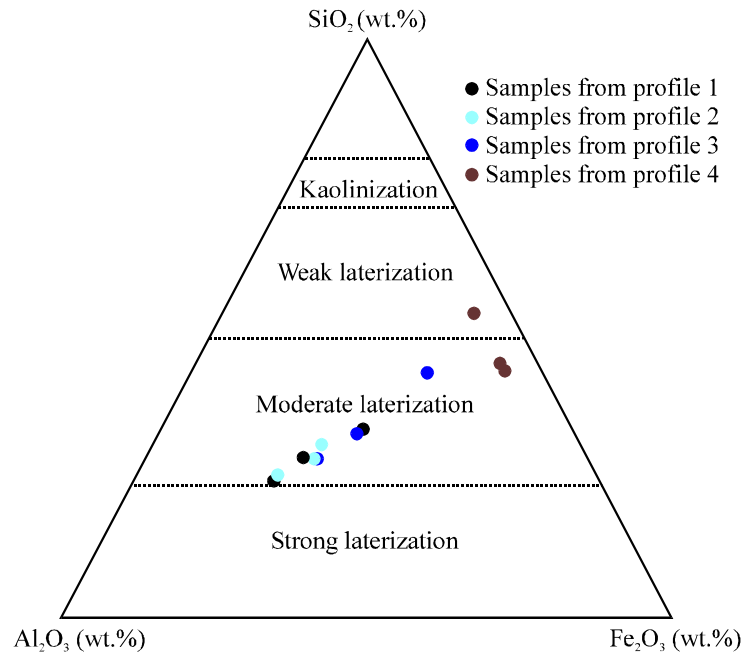

Fig. 5: The $\mathrm{Al}_{2} \mathrm{O}_{3}-\mathrm{SiO}_{2}-\mathrm{Fe}_{2} \mathrm{O}_{3}$ triangular diagram of bauxites showing degree of lateritization (Schellmann, 1982)

variation of other immobile element pairs have been used in the trace of the source rock for baxitization (MacLean et al., 1997, Abedini et al., 2008, Rafiei et al., 2008, Calagari, 2010; Esmaeily et al., 2010). MacLean (1990) and found that the immobile element pair that are well correlated with line passing through the origin for all bauxite units indicates one homogeneous source. Three separate trend lines indicate three 


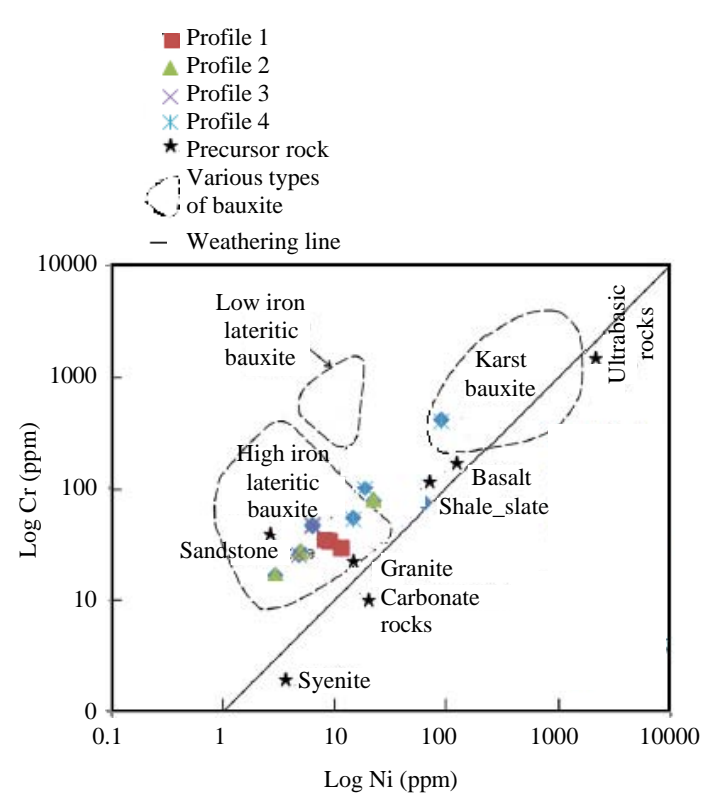

Fig. 6: Plot of $\mathrm{Ni}$ versus $\mathrm{Cr}$ concentration values for various types of bauxites in relation to various precursor rocks (Schroll, 1968)

different homogeneous sources while fan or random distribution indicates that one or more of the sources were heterogeneous. Plotting of $\mathrm{Fe}_{2} \mathrm{O}_{3}, \mathrm{TiO}_{2}$ vs. $\mathrm{Al}_{2} \mathrm{O}_{3}$ $(\mathrm{r}=-0.90)$ and few other trace elements; $\mathrm{Ba}, \mathrm{Sr}$ and $\mathrm{Zr}$ versus $\mathrm{Al}_{2} \mathrm{O}_{3}(0.04 \leq \mathrm{r} \leq 0.36)$ (Fig. 3) revealed heterogeneous sources for the bauxitic clay deposit at Orin-Ekiti.

\section{CONCLUSION}

Orin bauxitic clay is unconsolidated, fine-coarse grained texture deposit with brownish grey, light grey to nearly white colour. Major element chemistry revealed low alumina concentrations ( $25.64 \geq \mathrm{Al}_{2} \mathrm{O} \leq 34.19$ wt.\%) which does not meet approved standard value of $\mathrm{Al}_{2} \mathrm{O}_{3}$ $>45.0 \mathrm{wt}$ \% required for aluminum production. However, the bauxitic clay is suitable for the production of refractory bricks and ceramics while appropriate processing would be necessary if they are to meet requirements for other industrial applications such as rubber, paper, paint, cosmetics and fertilizer production. Alkalis and alkali earth elements showed low concentrations as they are highly mobile and leached off during weathering process. The ternary plot of $\mathrm{Al}_{2} \mathrm{O}_{3}-\mathrm{Fe}_{2} \mathrm{O}_{3}-\mathrm{SiO}_{2}$ indicated moderate lateralization with bauxitic clay representing $75 \%$ and silica $25 \%$. The binary $\mathrm{Cr} / \mathrm{Ni}$ plot indicated that the bauxitic clay was most likely to have originated from basic igneous and sedimentary rock. Orin bauxitic clay is not suitable for Al-ore beneficiation but could found uses in the production of refractory works, alum and fertilizers production.

\section{ACKNOWLEDGEMENT}

The reserachers thank the Tertiary Education Fund (TETFund) Nigeria for financial support provided for this project.

\section{REFERENCES}

Abedini, A., A.A. Calagari and B. Hadjalilu, 2008. Geological-mineralogical characteristics and trace-elements geochemistry in Aghadjari bauxite deposit, south of Shahindezh, NW of Iran. Iran. J. Crystallogr. Mineral., 16: 327-341.

Aleva, G.J.J. and D. Creutzberg, 1994. Laterites: Concepts, Geology, Morphology and Chemistry. International Soil Reference and Information Centre, Wageningen, Netherlands, ISBN:9789066720534, Pages: 169.

Ayorinde, A.O., 2011. Mineralogy and geochemistry of the bauxite deposits (Cretaceous), Wilkinson County, Georgia. MSc Thesis, Georgia State University, Atlanta, Georgia.

Babatunde, O.A. and O. Dayo-Olabgende, 2015. Evaluation of Bauxite from Orin-Ekiti, Ekiti State, South-West Nigeria using chemical and spectroscopic methods of analysis. Global J. Pure Appl. Chem. Res., 3: 15-19.

Balasubramaniam, K.S., M. Surendra and T.R. Kumar, 1987. Genesis of certain bauxite profiles from India. Chem. Geol., 60: 227-235.

Calagari, A.A., 2010. Geochemistry of major, trace and rare earth elements in Biglar Permo-Triassic bauxite deposit, Northwest of Abgarm, Ghazvin Province, Iran. J. Sci. Islamic Republic Iran, 21: 225-236.

Esmaeily, D., H. Rahimpour-Bonab, A. Esna-Ashari and A. Kananian, 2010. Petrography and geochemistry of the Jajarm Bauxite ore Deposit, Northeast Iran: Implications for source rock material and ore genesis. Turk. J. Earth Sci., 19: 267-284.

Kogel, J.E., N.C. Trivedi, J.M. Barker and S.T. Kurkowski, 2006. Industrial Minerals and Rocks. Society for Mining, Metallurgy and Exploration (SME), Englewood, Colorado, ISBN-13:978-0-87335-233-8, Pages: 1528 .

MacLean, W.H., 1990. Mass change calculations in altered rock series. Miner. Deposita, 25: 44-49. 
MacLean, W.H., F.F. Bonavia and G. Sanna, 1997. Argillite debris converted to bauxite during karst weathering: Evidence from immobile element geochemistry at the Olmedo Deposit, Sardinia. Miner. Deposita, 32: 607-616.

Madourie, M.A., 2013. A comparative analysis between Portuguese and Jamaican Bauxite Rocks: Their geo-economic potential for the aluminum industry. Master Thesis, University of Porto, Porto, Portugal.

Meyer, F.M., U. Happel, J. Hausberg and A. Wiechowski, 2002. The geometry and anatomy of the Los Pijiguaos bauxite deposit, Venezuela. Ore Geol. Rev., 20: 27-54.

Patterson, S.H., H.F. Kurtz, J.C. Olson and C.L. Neeley, 1986. World bauxite resources. United States Geological Survey, Reston, Virginia. https://pubs.er. usgs.gov/publication/pp1076B.

Plunkert, P.A., 2006. Bauxite and alumina. US. Geol. Surv., 10: $30-31$.
Rafiei, B., H. Mollai and M. Ghorbani, 2008. The genesis of Late Triassic allochthonous karst-type bauxite deposits of the Kisejin area, Ab-e-Garm district, Iran. N. Year Book Geol. Paleontol. Treatises, 250: 217-231.

Schellmann, W., 1982. [A new laterite definition (In German)]. Geol. Jahrb. Reihe D, 58: 31-47.

Schroll, E., 1968. [Contributions to the geochemistry of titanium, chromium, nickel, cobalt, vanadium and molybdenum in bauxite rocks and the problem of the material origin of aluminum (In German)]. Travaux ICSOBA., 5: 83-96.

Talabi, A.O., O.L. Ademilua, O.Z. Ajayi and S.O. Oguniyi, 2013. Preliminary geophysical evaluation of Orin Bauxite Deposit, Southwestern Nigeria. J. Emerging Trends Eng. Appl. Sci., 4: 432-437.

Valeton, I., 1972. Bauxites (Developments in Soil Science). Elsevier, Amsterdam, Netherlands, Pages: 226.

Wilson, M.J., 2004. Weathering of the primary rock-forming minerals: Processes, products and rates. Clay Min., 39: 233-266. 